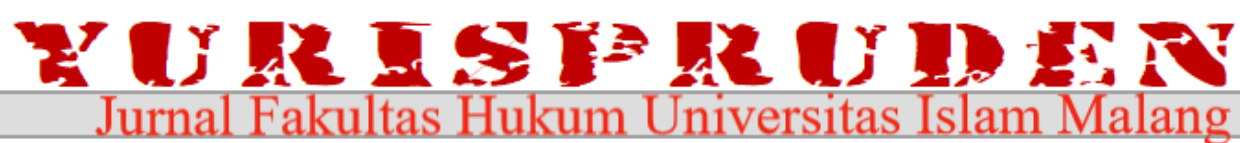 \\ Volume 5, Nomor 1, Januari 2022.
}

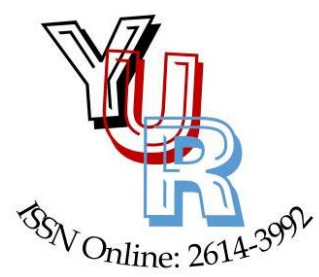

Editorial Office : Faculty of Law, Univeritas Islam Malang.

Jl. Mayjen Haryono No.193, Dinoyo, Kec. Lowokwaru, Malang, Provinsi Jawa Timur, 65144.

Phone $\quad$ :(0341) 551932 / 551822 / (0341) 552249

E-mail : yurispruden@unisma.ac.id

Website $\quad:$ http://riset.unisma.ac.id/index.php/yur/index

\section{Efektivitas Mekanisme Penyelesaian Sengketa Pulau Takeshima/Dokdo Melalui Jalur Non-Yuridis}

\section{Al Dina Maulidya}

Program Studi Hubungan Internasional

Fakultas Ilmu Sosial dan Ilmu Politik, Universitas Muhammadiyah Malang

Jl. Raya Tlogomas No. 246, Malang, Jawa Timur, Indonesia, 65144

E-mail: aldinamaulidyaa@gmail.com

Article

\section{Article History}

Received: May 18, 2020;

Reviewed: May 31, 2020;

Accepted: Oct 09, 2021;

Published: Jan 20, 2022;

DOI:

10.33474/yur.v5i1.6523

\section{Abstract}

This study aims to determine the effectiveness of the Takeshima/Dokdo Island dispute resolution mechanism between Japan and South Korea through non-juridical channels. The dispute has been started since the Japanese occupation in South Korea, so in this paper the author wants to examine the dispute resolution mechanism that has been carried out by Japan and South Korea in their efforts to resolve the Takeshima/Dokdo Island dispute. This type of research is normative legal research that emphasizes the approach to legislation. The results of this study indicate that the settlement mechanism carried out by Japan and South Korea using non-judicial channels is still not effective. The two countries have negotiated twice, namely in 1998 and 2006. In the same year as the second negotiation, South Korea decided to free itself from the UNCLOS dispute resolution. Then in 2018 Japan established a permanent connection to the island of Takeshima/Dokdo. South Korea's refusal to take the dispute to the International Court of Justice and the failure of negotiations, have left ambiguity over the ownership status of Takeshima/Dokdo islands.

Keywords: International Dispute Resolution, Takeshima Island, Dokdo Island, Japan, and South Korea.

Abstrak
Penelitian ini bertujuan untuk mengetahui efektivitas mekanisme
penyelesaian sengketa Pulau Takeshima/Dokdo antara Jepang dan
Korea Selatan melalui jalur non-yuridis. Sengketa tersebut telah
dimulai sejak zaman pendudukan Jepang di Korea Selatan,
sehingga pada tulisan ini penulis ingin meneliti mekanisme
penyelesaian sengketa yang telah dilakukan oleh Jepang maupun
Korea Selatan dalam upayanya menyelesaikan sengketa Pulau
Takeshima/Dokdo. Jenis penelitian ini adalah penelitian hukum
normatif yang menekankan pada pendekatan peraturan


perundang-undangan. Hasil dari penelitian ini menunjukkan jika mekanisme penyelesaian yang dilakukan Jepang dan Korea Selatan menggunakan jalur non-Yudisial, masih belum efektif. Kedua negara telah melakukan negosiasi sebanyak dua kali, yakni di tahun 1998 dan tahun 2006. Pada tahun yang sama dengan negosiasi kedua, Korea Selatan memutuskan untuk membebaskan diri dari penyelesaian sengketa UNCLOS. Kemudian Jepang di tahun 2018 mendirikan permanen terkait pulau Takeshima/Dokdo. Penolakan Korea Selatan untuk membawa sengketa ke Mahkamah Internasional serta ketidak berhasilan negosiasi, membawa ketidakjelasan bagi status kepemilikan pulau Takeshima/Dokdo).

Kata Kunci: Mekanisme Penyelesaian Sengketa Internasional, Pulau Takeshima, Pulau Dokdo, Jepang, dan Korea Selatan.

\section{PENDAHULUAN}

Sengketa internasional merupakan keadaan konflik yang terjadi diantara subjek hukum internasional yang mencakup fakta, hukum, atau politik dengan adanya tuntutan, klaim maupun pernyataan dari satu pilak yang ditolak, dituntut, maupun diingkari oleh pihak yang lain. ${ }^{1}$

Sengketa tersebut dapat terjadi karena beberapa penyebab, seperti terdapat perbedaan paham terkait suatu hal, adanya pelanggaran hak atau kepentingan milik negar lain yang dilakukan secara sengaja, perselisihan dua atau lebih negara terhadap suatu hal, dan melanggar hukum atau perjanjian internasional yang telah disepakati.
Sengketa bahkan dapat terjadi ketika negara telah memiliki hubungan dekat yang sudah lama dilakukan. Hubungan terjalin melalui banyaknya kerjasama baik secara bilateral maupun multilateral. Contoh dari hubungan bilateral ialah kerjasama Korea Selatan dengan Jepang. Hubungan bilateral antar keduanya telah berlangsung lebih dari 1.500 tahun, hubungan ini terjalin dengan melakukan pertukaran budaya, perdagangan serta melakukan kontak politik. ${ }^{2}$

Tahun 1965 menjadi kali pertama bagi Jepang dalam mengutus perdana menterinya ke Korea Selatan pasca perang antara keduanya. ${ }^{3}$ Setelah melewati tahun tersebut kedua negara memulai hubungan dekatnya dengan membangun kerjasama di bidang

\footnotetext{
${ }^{1}$ Julianto Jover Jotam Kalalo, (2016), Penyelesaian Sengketa Terhadap Kasus Imunitas Negara Melalui ICJ (International Court of Justice)/Mahkamah Internasional, Jurisprudentie: Jurusan Ilmu Hukum Fakultas Syariah dan Hukum, Volume 3, Nomor 2. hlm. 1.

2 Aldean Tegar Gemilang, (2015), Dampak Sengketa Pulau Dokdo/Takeshima Korea Selatan-Jepang Terhadap Perkembangan Hallyu Di Jepang Tahun 2012-2015, Dikases pada (__ ), Digital Liberary-Perpustakaan Pusat UNIKOM: https://elib.unikom.ac.id/gdl.php?mod=browse\&op=read\&id=jbptunikompp-gdl-aldeantega-33503.

3 VOA Indonesia, (2019), Untuk Perbaiki Hubungan, Jepang Dan Korsel Sepakat Adakan KTT Bulan Depan, Diakses pada (__ ), VO: https://www.voaindonesia.com/a/untuk-perbaiki-hubungan-jepang-dan-korselmengadakan-ktt-bulan-depan-/5178206.html.
} 
ekonomi dan budaya, yakni dengan berlangsung lama tanpa penyelesaian yang dimasukkannya Film animasi Jepang Astro jelas sehingga terus menerus menimbulkan Boy di tahun 1970-an ke Korea Selatan. ${ }^{4}$ Hal ini kemudian disusul dengan penayangan drama Winter Sonata tahun 2003 di Jepang oleh Korea Selatan. ${ }^{5}$

Keberlangsungan hubungan bilateral antara Jepang dengan Korea Selatan tidak selalu harmonis, sering kali terjadi pasang surut karena faktor masa lalu. Korea Selatan masih menyimpan dendam dengan Jepang yang menjajah mereka di tahun 1910-1945 atau selama 35 tahun. $^{6}$

Selama penjajahannya Jepang telah melakukan penindasan, memaksa para wanita Korea Selatan untuk melakukan praktik pelacuran, serta menjadikan para penduduk lainnya sebagai pekerja pabrik secara paksa. ${ }^{7}$ Selain faktor masa lalu yang memperburuk hubungan keduanya terdapat pula faktor lainnya yaitu sengketa perebutan Pulau ketegangan antara Jepang dan Korea Selatan.

Pulau sengeketa yang diperebutkan oleh Jepang dan Korea Selatan merupakan gugusan pulau karang tandus yang oleh Jepang disebut sebagai Pulau Takeshima dan Pulau Dokdo bagi Korea Selatan. ${ }^{9}$ Pulau ini memiliki luas sekitar $187,450 \mathrm{~m}^{2}$ yang meliputi dua pulau kecil serta beberapa pulau yang lebih kecil lainnya disekitar dua pulau tersebut. $^{10}$

Sengekta Pulau Takeshima/Dokdo telah berlangsung ketika Jepang mulai terlibat beberapa urusan di semenanjung Korea. Jepang pada Februari 1904 melakukan perang terhadap Rusia yang kemudian menyerang dua kapal Rusia di sekitaran Pulau Palmido, yakni daerah luar dari Pelabuhan Incheon milik Korea. ${ }^{11}$ Beberapa jam setelahnya Jepang berhasil mengendalikan Pelabuhan Takashema/Dokdo. ${ }^{8}$ Sengeta ini telah Incheon dan meletakkan beberapa

4 Firman Budianto, (2015), Tinjauan Buku Anime, Cool Japan, dan Globalisasi Budaya Populer Jepang, Jurnal Kajian Wilayah, Volume 6, Nomor 2. hlm. (__ $)$.

5 Irvan Sjafari, (2013), Invasi K-Pop Juga Terasa Di Jepang: Sebuah Catatan, Diakses pada (__), Kompasiana.com: https://www.kompasiana.com/jurnalgemini/552b3fee6ea834512d552d27/invasi-kpopjuga-terasa-di-jepang-sebuah-catatan.

6 Aldean Tegar Gemilang, Lo.cit.

7 Yosi Winosa, (2019), Ini Alasan Jepang Berseteru Dengan Korea Selatan, Diakses pada (__), Wartaekonomi.co.id,: https://www.wartaekonomi.co.id/read236957/ini-alasan-jepang-berseteru-dengankorea-selatan.html.

8 John Chan, (2006), Ketegangan Antara Jepang Dan Korea Selatan Semakin Meningkat Karena Perselisihan Pulau, Diakses pada (__), World Socialist Web Site: https://www.wsws.org/en/articles/2006/05/japam03.html.

9 Utami Gita Syafitri, (2013), Sengketa Pulau Dokdo Antara Jepang Dan Korea Selatan, Jurnal of USU: International Law, Volume 1, Nomor 2. hlm. 3.

10 Dian Adilia Sarsa Gardina, (2018), Sengketa Pulau Takeshima (Dokdo) Antara Jepang Dan Korea Selatan Dalam Perspektif Realisme, UNPAS REPOSITORIES \& SCIENTIFIC JOURNALS Volume 2, Nomor (__ $)$, hlm. (_ $)$.

11 (__ $),(2009)$, Korea's Political Situation in 1905 and Japan's Annexation of Dokdo, Diakses pada (_ $)$, Dokdo-Takeshima.com: https://www.dokdo-takeshima.com/koreas-political-situation-dokdo.html. 
pasukannya dijalanan Korea untuk berpatroli, dua minggu setelahnya Jepang berhasil mendesak Presiden Korea di Seoul untuk menandatangani Protectorate of Japan over Korea. $^{12}$

Pada Pasal IV protokol tersebut menyatakan, "Pemerintah imperal Jepang dapat, untuk mencapai objek yang disebutkan di atas (Korea), jika memang ada keadaan yang mengharuskannya (Jepang), tempattempat (tindakan) seperti itu mungkin diperlukan dari sudut pandang strategis (Jepang)", ${ }^{13}$

Pasal IV Protectorate of Japan over Korea telah memperjelas kedudukan Jepang di Korea yang sekaligus memberikan izin kepada Jepang "secara hukum" untuk melakukan operasi militer di Korea. Bulan Agustus 1904 Jepang mengambil alih segala urusan luar negeri Korea dan dilanjutkan dengan mengendalikan segala sistem komunikasi Korea di tahun $1905 .{ }^{14}$

Pada 22 Februari 1905 Jepang telah melakukan pengambilan alih pulau Dokdo secara diam-diam tanpa memberitahu pemerintah maupun rakyat Korea, Jepang kemudian menamai pulau tersebut dengan nama Takeshima. ${ }^{15}$ Pengambilan alih pulau ini diawali oleh keinginan nelayan Jepang untuk memasukan pulau Dokdo ke dalam wilayah Jepang karena mereka telah melakukan penangkapan singa laut di perairan sekitaran pulau Dokdo. ${ }^{16}$

Pulau Dokdo oleh Jepang pada awalnya dilihat sebagai pulau tandus yang tak berpenghuni. Setelah mengambil alih pulau tersebut Jepang membangun menara komunikasi untuk mempermudah armada perangnya melawan Rusia. ${ }^{17}$

Pada Maret 1906 fakta yang tersebut akhirnya terkuak dan menimbulkan penentangan dari masyarakat Korea. ${ }^{18}$ Namun, dengan tidak adanya lagi Kementerian Luar Negeri Korea sejak 1904, maka kemampuan Korea untuk mengajukan protes atau klaim resmi di tingkat negara ke negara juga telah hilang. ${ }^{19}$

Perjuangan Korea untuk mengambil kembali pulau Takeshima/Dokdo masih terkendala dengan penjajahan Jepang di Korea pada tahun $1910-1945 .{ }^{20}$ Berakhirnya Perang Dunia ke-II memberikan keuntungan bagi Korea, yakni dengan diraihnya kemerdekaan yang disusul dengan

\footnotetext{
12 Ibid.

13 (__), (1904), Protectorate of Japan over Korea, Diakses pada (_ _ ), Dokdo-Takeshima.com: https://www.dokdo-takeshima.com/wordpress/wp-content/images/japan-korea-treaty5.jpg.

14 Ibid.,

15 Syafitri, (_), Sengketa Pulau Dokdo Antara Jepang Dan Korea Selatan, (__ ), (__), (__ ). hlm. 7.

16 Egie Sagita, (2010), Upaya Diplomatik Korea Selatan-Jepang Terhadap Penyelesaian Sengketa Kepulauan Dokdo, Diakses pada (__ ), (__ ): https://vdocuments.site/jbptunpaspp-gdl-egiesagita-514-1-skripsi-i.html.

17 Ibid.

18 Ibid.

19 Ibid.

20 Aldean Tegar Gemilang, Lo.Cit.
} 
terpecahnya Korea sekaligus menandakan berdirinya Korea Selatan pada 15 Agustus $1948 . .^{21}$

Di tahun 1965 Jepang dan Korea Selatan memulai hubungan bilateralnya, hal ini ditandai dengan disepakatinya Japan and Republic of Korea Treaty on Basic Relations. Kesepakatan ini tidak hanya mengawali hubungan kerjasama di bidang politik tetapi juga pengakuan Jepang atas berdirinya Repubik Korea Selatan, hal ini tertuang di dalam Pasal III Japan and Republic of Korea Treaty on Basic Relations yang menyatakan, "Telah dipastikan jika Pemerintah Republik Korea adalah satu-satunya pemerintah yang sah di Korea sebagaimana ditentukan dalam Resolusi 195 (III) oleh Majelis Umum Perserikatan Bangsa-Bangsa". 22

Tahun demi tahun yang terlewat dengan menjalin hubungan kerjasama di berbagai aspek tidak memudarkan keinginan Jepang dan Korea Selatan untuk kembali memperebutkan Pulau Takeshima/Dokdo.

Korea Selatan sebagai negara yang merdeka jelas telah memiliki kekuatan untuk melakukan klaim terhadap wilayah yang dianggap sebagai bagian dari negaranya. Jepang kembali memulai klaimnya atas Pulau
Takeshima/Dokdo di tahun 2005 dengan menetapkan pulau tersebut sebagai bagian dari Perfektur Shimane dan didukung dengan ditetapkannya "Takeshima Day" yang akan diperingati setiap tanggal 22 Februari (hari dimana Jepang mendapatkan dan menamai pulau tersebut). ${ }^{23}$

Pada tahun 2006 Jepang berencana untuk melaukan survei maritim terhadap Pulau Takeshima/Dokdo yang kemudian ditanggapi serius oleh Korea Selatan dengan ancaman akan mengirimkan 20 kapal meriam jika Jepang tetap ingin melaksanakan survei maritim tersebut. ${ }^{24}$

Pada tahun yang sama, Roh Moo-hyun sebagai Presiden Korea Selatan saai itu memberikan special statement untuk memperjelas sikap negaranya terhadap hubungan Korea Selatan-Jepang dan mendesak Jepang untuk mengimplementasikan permintaan maafnya atas kolonialisasi mereka di Korea dalam bentuk tindakan yang nyata, berikut pernyataan tersebut:

"Rekan-rekan Koreaku, Dokdo adalah tanah kita. Itu bukan hanya sebidang tanah kita tetapi juga signifikansi historis yang menjadi bukti nyata akan penderitaan kita selama empat puluh tahun. Dokdo adalah wilayah pertama Korea yang direbut oleh Jepang atas Semenanjung Korea. Perang

21 KBS World Radio, (2016), Tahun 1940-an: Kemerdekaan Dan Terbagi Duanya Korea, Diaksespada (_ _ ), World.kbs.co.kr: http://world.kbs.co.kr/special/northkorea/contents/archives/outline/outline_1940.htm?lang=i.

22 United Nation-Treaty Series, (1966), JAPAN and REPUBLIC OF KOREA Treaty on Basic Relations., Diakses pada (__ $)$, (__ $)$ : https://treaties.un.org/doc/Publication/UNTS/Volume 583/volume-583-I-8471-English.pdf.

23 Fauzia Dyah Ayu Paramitha, (2013), Strategi Jepang Dan Korea Selatan Dalam Menyelesaikan Sengketa Teritorial Pulau Takeshima/Dokdo, Jurnal Analisis Hubungan Internasional, Volume 2, Nomor 3. hlm. 3.

24 Ibid., hlm. 5-6. 
Rusia-Jepang adalah perang agresi yang diinisiasi Keakisaran Jepang untuk mengamankan kontrol atas Semenanjung Korea. Dengan dalih melaksanakan perang, Jepang mengirimkan pasukannya ke Korea dan menduduki Semenanjung Korea... di tengah-tengah proses inilah Jepang dengan paksa menggabungkan Dokdo ke dalam wilayahnya... Saya ingin meminta dengan bersungguh-sungguh kepada rekan dan pemimpin Jepang, kami tidak lagi menuntut permintaan maaf baru. Kami hanya menyerukan tindakan yang akan berlaku adil untuk permintaan maaf yang telah dilakukan berulang kali... Jepang harus berdiri tegak dengan berani melepaskan diri dari bab gelap dalam sejarah agresi imperialisnya. Kami sedang menunggu tekad Jepang untuk perdamaian dan kemakmuran Asia Timur abad ke-21 dan, lebih jauh, perdamaian di dunia. Terima kasih.".25

Pasca special statement dari Presiden Roh Moo-hyun, sebuah organisasi yang berada di bawah The Korea Institute of Geoscience \& Mineral Resources melakukan kegiatan pengeboran pada cekungan Ulleung sekitaran pulau Takeshima/Dokdo. ${ }^{26}$

Kegiatan tersebut bertujuan untuk mencari tahu potensi sumber daya alam dai pulau karang tandus tersebut. Pada tahun 2007 Korea Selatan mengumumkan penemuannya, sekitar 600 juta ton gas hidrat berada di daerah cekungan Ulleung, Laut Jepang. ${ }^{27}$
Gas hidrat merupakan Kristal padat yang terdiri dari sekumpulan air dan gas metana, kepadatan energi gas hidrat jauh lebih tinggi daripada gas alam lainnya. ${ }^{28}$ Diperkirakan 600 juta ton gas hidrat yang ditemukan dapat memenuhi kebutuhan energi Korea Selatan selama 30 tahun. ${ }^{29}$

Penemuan gas hidrat semakin membuat Pemerintahan Jepang semakin mempertegas kepemilikannya atas Pulau Takeshima/ Dokdo, hal ini dibuktikan dengan dimasukkannya informasi kepulauan Takeshima di dalam buku pelajaran bagi kurikulum pendidikan sekolah menengah di Jepang pada tahun $2008 .^{30}$

Klaim kali ini dilakukan dengan memberikan informasi kepada para siswa Jepang jika Pulau Takeshima adalah milik mereka, oleh karena itu negara lain seperti Korea Selatan seharusnya tidak mengklaimnya. Tentu saja hal ini membawa protes bagi masyarakat Korea Selatan, "Jika Jepang mencoba mengambil pulau ini dari kami, maka kami akan berjuang sampai akhir... Jika kami kehabisan senjata, kami akan membenturkan kapal kami untuk

25 Embassy of The Republic of Korea in The Republic of Kenya, (2006), Special Message by President Roh MooHyun on Korea-Japan Relations, Diakses pada (__, (__): http://overseas.mofa.go.kr/keen/brd/m_10548/view.do?seq=613445\&srchFr=\&amp;srchTo=\&amp;srchWord=\&amp;srchTp=\&amp;multi _itm_seq=0\&amp;itm_seq_1=0\&amp;itm_seq_2=0\&amp;company_cd=\&amp;company_nm=\&page $=8$.

26 T\&B Petroleum, (2010), S. Korea to Tap Gas Hydrate Reserves in East Sea, Diakses pada (_ _), tbpetroleum.com: https://tbpetroleum.com.br/news/s-korea-to-tap-gas-hydrate-reserves-in-east-sea/.

27 Syafitri, Op.cit. hlm. 9.

28 Ibid.

29 Paramitha, Op.cit. hlm. 4.

30 Jeffrey Hays, (2013), South Korea and Japan Dispute over The Takeshima-Dokdo Island and Japan Sea Name, Diakses pada (__ ), (__ ) : http://factsanddetails.com/japan/cat22/sub149/item2922.html. 
melawan penyusup kebanggaan nasional kami dipertaruhkan.". ${ }^{31}$

Dua tahun berselang, pengeboran kedua kembali dilakukan oleh Korea Selatan untuk memeriksa kepastian dari jumlah gas hidrat yang terkandung disekitaran pulau takeshima/Dokdo. ${ }^{32}$ Gas Hydrate $R \& D$ Organization kali ini melakukan pemerikasaan pada kedalaman lebih dari 1.800 meter dan di 10 titik yang berbeda. ${ }^{33}$

Pada tahun 2011 tiga anggota Partai Demokrat Liberal Konservatif Jepang datang ke Korea Selatan dan ingin menuju Museum Dokdo di Pulau Ulleungdo dan berencana untuk mencari materi pengetahuan yang berkaitan tentang klaim Korea Selatan atas pulau yang oleh Jepang diakui sebagai milik mereka. ${ }^{34}$

Tiga anggota parlemen itu kemudian tidak mendapatkan izin untuk keluar dari Bandara Gimpo Seoul dengan alasan keselamatan, diluar banadara tersebut telah diketahui jika sejumlah masyarakat sipil Korea yang menentang klaim Jepang atas
Pulau Takeshima/Dokdo telah menunggu mereka dengan membawa tiga peti mati.$^{35}$

Lee Jae Oh, tangan kanan Presiden Lee Myung-bak mengunjungi pulau yang bersengketa tersebut dan mengatakan dalam cuitan twitternya, "Saya akan tinggal di sini (Pulau Takeshima/Dokdo) sampai anggota parlemen Jepang pergi... Aku akan menunjukkan kepada mereka dengan jelas jika tidak ada tanah di sini bagi mereka untuk menginjakan kaki." 36

Setelah berselang satu tahun dari kejadian kontroversial tersebut, di tahun 2012 Korea Selatan kembali ingin menunjukkan taringnya kepada Jepang. Presiden Korea Selatan saat itu, Lee Myung-bak bersama anggota parlemen Komite Pertahanan Nasional mengunjungi Pulau takeshima/Dokdo. ${ }^{37}$

Ini merupakan kunjungan ke-3 bagi anggota parlemen Komite Pertahann Nasional Korea Selatan, setelah kunjungan sebelumnya di tahun 2005 dan 2008 dengan tujuan yang sama yaitu melakukan patroli keamanan ${ }^{38}$ Tindakan Korea Selatan kali ini telah melibatkan masyarakat Jepang untuk

31 Choe Sang Hun, (2008), Desolate Dots in the Sea Stir Deep Emotions as South Korea Resists a Japanese Claim, Diakses pada (__ $)$, The New York Times: https://www.nytimes.com/2008/08/31/world/asia/31 islands.html.

32 Byong-Jae Ryu, (2016), Gas Hydrates in The Deep Water Ulleung Basin, East Sea, Korea, Geophysical Research Abstracts, Volume 18, Nomor ( . hlm.

33 T\&B Petroleum, Lo.cit.

34 Jeffrey Hays, Lo.cit.

35 Choe Sang Hun, (2011), Japanese Lawmakers Denied Entry in South Korea, Diakses pada (__), The New York Times: https://www.nytimes.com/2011/08/02/world/asia/02korea.html.

36 Ibid.

37 BBC, (2012), South Korea's Lee Myung-Bak Visits Disputed Islands, Diakses pada (__), BBC: https://www.bbc.com/news/world-asia-19204852.

38 Ibid. 
memberikan reaksi. Pada tahun yang sama, publik Jepang menolak hadirnya para bintang Hallyu. ${ }^{39}$

Gelombang ketegangan atas sengketa yang kembali menerpa Jepang memberikan celah bagi para anti-Hallyu di Jepang untuk menyebarkan nilai nasionalis Jepang dengan meningkatkan sentiment negatif yang memang telah ada dimasyarakat mengenai produk budaya Korea Selatan di negaranya. ${ }^{40}$ Pada tahun yang sama, Pemerintah Jepang kembali mengajukan penyelesaian sengketa ke Mahkamah Internasional dan tetap ditolak oleh Korea Selatan. ${ }^{41}$

Seiring dengan meredanya isu sengketa di tahun 2016 antar kedua negara yang terkait, Hallyu kembali digemari oleh masyarakat Jepang. Hal ini dibuktikan dengan hadirnya 15.000 masyarakat Jepang untuk memeriahkan Festival KCON. ${ }^{42}$

Meredanya isu sengketa di tahun 2015 antara Jepang dengan Korea Selatan tidak bertahan lama, Jepang kembali menyulut amarah Korea Selatan. Pada tahun 2018 Jepang meresmikan eksebisi permanen terkait dokumen, artikel, dan foto yang memihak klaim Jepang terhadap Pulau
Takeshima/Dokdo ${ }^{43}$. Peresmian dilakukan di Museum Nasional Teritori dan Kedaulatan yang berada di Kota Tokyo pada tanggal 25 Januari $2018 .{ }^{44}$ Hal ini kembali memberikan gesekan terhadap hubungan Jepang dengan Korea Selatan.

Sengekta wilayah yang terjadi antara satu negara dengan negara lainnya bukan lagi hal yang baru di dalam hukum internasional. Wilayah suatu negara di dalam dukum Internasional dipandang sebagai sesuatu yang mutlak dalam pembentukan suatu negara, hal ini dikarenakan wilayah merupakan tempat dimana penduduk suatu negara dapat bermukim. $^{45}$

Menurut Mauna Boer yang dikutip oleh Gardina di dalam karyanya, Kedaulatan tertinggi dari sebuah negara dibatasi melalui batas negara atau batas wilayah dari negara tersebut. $^{46}$

Dengan demikian penting bagi sebuah negara untuk memperjelas batas wilayah negaranya, ketika terdapat penyalahgunaan atau pelanggaraan atas wilayahnya maka negara tersebut apat melakukan protes dan klaim karena memiliki kedaulatan penuh atas wilayah negaranya. Pentingnya wilayah ini

39 Liputan6, (2012), Omg, Jepang Tolak Konser Kpop!, Diakses pada (__), Liputan6.Com: ttps://Www.Liputan6.Com/Showbiz/Read/453570/Omg-Jepang-Tolak-Konser-Kpop.

40 Anniza Kemala, (Juli, 2018), Globalisasi Industri Hiburan Jepang Dan Korea: Pengaruh Terhadap Perspektif Publik Antar Negara, Global: Jurnal Politik Internasional, Volume 20, Nomor 2. hlm. 207.

41 Paramitha, Op.cit. hlm. 5.

42 Aldean Tegar Gemilang, Op.cit. hlm. 111.

43 Kbs World, (2018), Jepang Kembali Mengklaim Kepemilikan Pulau Dokdo, Diakses pada (__), KBS WORLD RADIO: http://world.kbs.co.kr/service/news_view.htm?lang=i\&Seq_Code=51456.

44 Ibid.

45 Gardina, Op.cit. hlm. 1.

46 Ibid. 
kemudian menimbulkan perebuatan atau sengketa wilayah, baik itu wilayah darat, wilayah laut maupun perebutan pulau. Sengketa wilayah sering terjadi antara negara yang berdekatan letaknya. ${ }^{47}$ Hukum internasional juga memiliki solusi dalam penyelesaian sengketa internasional.

Penting bagi sebuah negara untuk menyelesaikan sengketa negaranya, karena sengketa dapat menciptakan hubungan buruk, menghambat terjalinnya kerjasama, membentuk citra buruk negara, dan ada kemungkinan menyebabkan terjadinya perang. Oleh karena itu, penulis tertarik untuk mengakaji, mempelajari, serta menganalisis fenomena dari sengketa Pulau Takeshima/Dokdo dan mengetahui mekanisme penyelesaian sengketa yang telah dilakukan Jepang dan Korea Selatan.

Sengketa Pulau Takeshima/Dokdo memang memiliki bahasan yang panjang dan kompleks. Penulis memandang jika diperlukan pembatasan ruang lingkup penelitian. Penulis akan membahas mekanisme penyelesaian sengketa dalam hukum internasional yang telah dilakukan oleh Jepang dan Korea Selatan. Dengan demikian untuk memudahkan penulis dalam melakukan pembahasan dalam penelitian ini, penulis menetapkan rumusan masalah sebagai berikut: "Bagaimana efektivitas mekanisme penyelesaian

sengketa

pulau

Takeshima/Dokdo melalui jalur non-yuridis?"

Adapun penelitian ini merupakan penelitian hukum normatif. Sengeketa perebutan pulau oleh Jepang dan Korea Selatan memerlukan penyelesaian agar konflik yang ada tidak berlarut-larut dan memberikan kedamaian bagi kedua negara. Melalui penelitian ini penulis ingin mengetahui dasar klaim dari Jepang dan Korea Selatan, mencari cara penyelesaian sengketa secara umum dan berdasarkan piagam PBB serta ingin mengetahui langkahlangkah penyelesaian sengketa Pulau Takeshima/Dokdo oleh Jepang dan Korea Selatan.

Cara penyelesaian sengketa atau mekanisme penyelesaian sengketa tersebut akan diperoleh dari dasar hukum yang bersumber dari hukum internasional terkait penyelesaian sengketa internasional.

Penelitian hukum normatif merupakan penelitian yang mengkaji asas, konsep hukum, serta menggunakan sumber data sekunder yang berasal dari peraturan tertulis, perundang-undangan, keputusan pengadilan, dan dasar hukum. ${ }^{48}$

Penulis memandang jika penelitian hukum normarif dengan tepat menggambarkan jenis penelitian ini. Pendekatan yang digunakan oleh penulis ialah pendekatan peraturan perundang-undangan

47 Ibid.

48 Rianto Adi, (2004), Metodologi Penelitian Sosial dan Hukum, (__ ); Granit, hlm. 92. 
dan melakukan analisis bahan hukum yang diperoleh secara diskriptif, analisis, dan argumentatif.

Sumber data yang digunakan penulis merupakan bahan hukum sekunder, yakni dengan menggunakan bahan bacaan yang memberikan penjelasan terkait permasalahan dalam penelitian sebagai bahan hukum primer dan sekunder. Data tersebut akan dikumpulkan melalui teknik studi kepustakaan.

Teknik ini dapat dilakukan dengan cara membaca, menelaah serta membuat catatan dari bahan yang bersumber dari buku, jurnal ilmiah, skripsi, berita, internet serta sumber lainnya. Dalam penelitian ini akan digunakan sumber bacaan yang berkaitan dengan sengketa Pulau Takeshima/Dokdo yang berasal buku, jurnal ilmiah serta berita di internet. Penggunaan studi kepustakaan dipandang mampu memberikan keefektifitasan dalam mengumpulan data yang diperlukan dalam penelitian ini.

\section{PEMBAHASAN}

Dasar Klaim Jepang Terhadap Pulau Takeshima/Dokdo

Kekalahan Jepang di Perang Dunia ke-II secara otomatis telah memberikan kewenangan kembali kepada negara jajahannya untuk memiliki wilayah negara mereka secara penuh. Hal-hal yang berkaitan dengan wilayah jajahan Jepang, perdamaian pasca Perang Dunia ke-II, serta tanggung jawab Jepang sebagai negara yang menanggung beban biaya kekalahan perang dunia telah dicantumkan dalam Perjanjian San Fransisco tanggal 8 September 1951.

Dalam Bab II Perjanjian San Fransisco yang berjudul Territory, pada Pasal 2 nya telah memuat enam poin terkait pengakuan Jepang yang melepaskan beberapa pulau jajahannya terdahulu. Terkait pengakuan Jepang yang melepaskan pulau jajahannya di Korea tercantum pada poin pertama yang menyatakan, "...Jepang, mengakui kemerdekaan Korea, meninggalkan hak, jabatan dan klaim ke Korea, termasuk kepulauan Quelpart, Port Hamilton dan Dagelet...". 49

Pada poin pertama Pasal 2 Bab II Perjanjian Fransisco tidak menyebutkan jika Jepang melepaskan klaimnya atas Pulau Dokdo. Hal inilah yang kemudian dijadikan dasar dari klaim Jepang terhadap Pulau Takeshima/Dokdo. Jepang mengaku tidak pernah mengembalikan Pulau Dokdo kepada Korea Selatan dan telah mengklaim jika Pulau Dokdo merupakan bagian dari wilayah Jepang sejak 1905 yang diubah namanya menjadi Pulau Takeshima. ${ }^{50}$

49 United Nation-Treaty Series, (1951), Argentina, Autralia, Belgium, Bolivia, Brazil,Etc.Treaty of Peace with Japan (with Two Declarations), Diakses pada (__ ), San Fransisco: https://treaties.un.org/doc/publication/unts/volume 136/volume-136-i-1832-english.pdf.

50 The Commissioned Research Report on, Takeshima-related, and Documents, (2017), Commissioned Research Report on the Takeshima-Related Documents FY2016 Cabinet Secretariat Commissioned Research Project 
Hal ini sesuai dengan putusan Dewan Prefektur Shimane no. $40 .{ }^{51}$ Putusan tersebut memperkuat kepemilikan Jepang atas Pulau Takeshima/Dokdo, karena legalitasnya jelas dan bersifat resmi serta mengikat secara yuridis. Berikut isi dari putusan Dewan Prefektur Shimane no. 40:

"...Pulau-pulau ini (Takeshima/ Dokdo) terletak di $37^{\circ} 9$ ' 30 "Lintang Utara dan $131^{\circ} 55$ 'Bujur Timur, jarak 85 mil laut sebelah barat dari Pulau Okinawa, akan ditetapkan sebagai Takeshima, dan dengan ini ditempatkan di bawah yurisdiksi Kantor Cabang Okinawa di prefektur ini (Shimane). Bukichi Matsunaga, Gubernur Prefektur Shimane...".52

\section{Dasar Klaim Korea Selatan Terhadap Pulau Takeshima/Dokdo}

Berbeda dengan dasar klaim Jepang yang bersumber dari perjanjian internasional, Korea Selatan melontarkan klaim atas Pulau Takeshima/Dokdo berdasarkan sejarahnya. Sebuah dokumen sejarah mencantumkan jika Pulau Takeshima/Dokdo pada awalnya dipandang oleh Korea Selatan sebagai pulau tak berpenghuni dan tak berkepemilikan sehingga dinamakan Ussankuk. ${ }^{53}$ Pada Dinasti Shila sekitar tahun 512 SM, pulau tersebut bergabung dengan dengan Korea Selatan dan legalitasnya tercantum dalam dokumen sejarah pada masa kekaisaran Korea Selatan. ${ }^{54}$

Dasar klaim lain dari Korea Selatan ialah Rhee Line. Salah seorang presiden dari Korea Selatan, Rhee Sygman mengeluarkan sebuah deklarasi presiden pada tanggal 18 Januari 1952. ${ }^{55}$ Isi dari deklarasi tersebut menyatakan jika telah dibuat sebuah garis khayal yang diberi nama Rhee Line yang akan memberikan batas wilayah antara Korea Selatan dengan Jepang.

Garis ini memperlihatkan jika sebagian Laut Jepang termasuk Pulau Takeshima/ Dokdo merupakan bagian dari Korea Selatan. Sejak itu Korea Selatan mulai menguasai pulau tersebut secara fisik, langkah pertamanya dengan membangun mercusuar di tahun $1954 .^{56}$ Kemudian diikuti langkah selanjutnya dengan menurunkan sejumlah petugas penjaga pulau yang akan berpatroli menjaga Pulau Takeshima/Dokdo dari campur tangan pihak lain, terutama Jepang. ${ }^{57}$

Dasar klaim terakhir yang dilontarkan oleh Korea Selatan ialah letak geografis Pulau Takeshima/Dokdo. Jika dilihat dari letaknya, pulau tersebut berada paling dekat dengan Pulau Ullengdo (milik Korea Selatan) dan

\footnotetext{
Takeshima-, Diakses pada (_ _, (_): https://www.cas.go.jp/jp/ryodo_eg/img/data/archivestakeshima03.pdf.

51 Ibid.

52 Arata Yokokawa, (2015), Takeshima, Diakses pada (__ ), (__ ): https://www2.jiia.or.jp/en/pdf/digital_library/Yokokawa_takeshima.pdf.

53 Gardina, Op.cit. hlm. 3.

54 Ibid.

55 Syafitri, Op.cit. hlm. 7.

56 Ibid.

57 Ibid.
} 
Pulau Oki (milik Jepang). Jarak dari Pulau Ullengdo menuju Pulau Takeshima/Dokdo ialah 87 km, sedangkan jarak dari Pulau Oki ke Pulau Takeshima/Dokdo adalah 157,5 km jauhnya. 58

Selain letak Pulau Takeshima/Dokdo yang lebih dekat dengan Korea Selatan, pulau tersebut juga dapat dilihat dari Pulau Ullengdo. ${ }^{59}$ Sedangkan dari Pulau Oki milik Jepang, pulau tersebut tidak dapat dilihat. Menurut Korea Selatan hal ini membuktikan jika memang pemilik dari Pulau Takeshima/Dokdo adalah negaranya.

Cara Penyelesaian Sengketa Internasional Secara Umum dan Berdasarkan Piagam PBB

Cara penyelesaian sengketa internasional secara umum dapat diselesaikan dengan menempuh jalur negosiasi. ${ }^{60}$ Negosiasi dapat mencapai keberhasilan jika memang kedua pihak yang bersengketa menginginkan solusi untuk menyelesaikan sengketa tersebut. namun, negosiasi tidak akan dapat dilakukan jika memang kedua negara tidak ingin melakukan hal tersebut. Menurut Huala Adolf yang dikutip oleh Primayanthi, negosiasi juga tidak dapat dilakukan jika kedua negara tidak memiliki hubungan diplomatik. ${ }^{61}$ Dengan demikian, negara yang tidak memiliki hubungan diplomatik tetapi menginginkan jalan negosiasi dapat diatasi dengan melibatkan orang ketiga. Pihak ketiga dapat memberikan jalan dalam penyelesaian masalah melalui good office dan mediasi. ${ }^{62}$

Perserikatan Bangsa-Bangsa (PBB) telah menjadi organisasi internasional yang memiliki pengaruh besar dalam menumbuhkan kerjasama antar bangsa pada berbagai macam sektor kehidupan. Selain memberikan jalan untuk mengembangkan kerjasama, PBB juga memiliki tugas untuk menyelesaikan kasus-kasus internasional antarbangsa.

Hal tersebut telah tercantum di dalam Piagam PBB, "Kami orang-orang dari negaranegara bersatu dan bertekad untuk menyelamatkan kesuksesan generasi dunia dari dorongan perang...".63 Tugas ini tidak terlepas dari tujuan terbentuknya PBB sebagai organisasi yang akan menciptakan perdamaian, hal tersebut telah tercantum di dalam Pasal 1 Piagam PBB sebagai berikut:

"Untuk menjaga perdamaian dan keamanan internasional maka akan diambil langkah-langkah kolektif yang efektif untuk pencegahan dan penghapusan ancaman terhadap perdamaian, dan untuk penindasan tindakan agresi atau pelanggaran perdamaian lainnya, dan

58 The Historical Facts of the Dokdo Dispute, Lo.cit.

59 Syafitri, Lo.cit

60 Ida Primayanthi, (2015), Mekanisme Penyelesaian Sengketa Internasional (Studi Kasus Nikaragua-Amerika Serikat)" ( $)$, Volume 3, Nomor 2. hlm. 3

61 Ibid.

62 Ibid

63 United Nation, (1945), UN Charter, Diakses pada (__ ), un.org: https://www.un.org/en/sections/un-charter/uncharter-full-text/. 
untuk mewujudkan dengan cara damai, dan sesuai dengan prinsip-prinsip keadilan dan hukum internasional, penyesuaian atau penyelesaian sengketa atau situasi internasional yang mungkin mengarah pada pelanggaran perdamaian.". ${ }^{64}$

Isi dari piagam tersebut kemudian dijadikan dasar bagi PBB untuk bertindak dan berperan aktif dalam menyelesaikan berbagai kasus-kasus internasioal, salah satunya ialah sengketa internasional. Prinsip penyelesaian sengketa internasional oleh PBB telah tercantum di dalam Pasal 2 Ayat (3) Piagam PBB, "Semua anggota harus menyelesaikan sengket internasional mereka dengan cara damai sedemikian rupa sehingga perdamaiana dan keamanan internasional dan keadilan tidak akan terancam punah.”. ${ }^{65}$ Mekanisme penyelesaian sengketa internasional di dalam hukum internasional lebih jelas di atur dalam Pasal 33 Ayat (1) Bab VI Piagam PBB dengan judul Pasific Settlement of Disputes:

"Para pihak yang sedang bersengkata yang berkelanjutan cenderung membahayakan pemeliharaan perdamaian dan keamanan internasional, pertama-tama harus mencari solusi melalui negosiasi, penyelidikan mediasi, konsiliasi, arbitrasi, penyelesaian peradilan, resor ke badanbadan regional atau pengaturan, atau cara damail lainnya pilihan mereka sendiri.". 66

Isi dari pasal ini kemudian menjadi acuan dalam mekanisme penyelesaian sengketa internasional dan memberikan solusi penyelesaiannya. Jadi, penyelesaian sengketa internasional dapat dilakukan dalam dua jalur. Jalur pertama ialah dengan jalur Yudisial, dimana sengeta yang ada akan disekesaikan secara formal dan melibatkan pihak ketiga yaitu arbitrase dan Mahkamah Internasional.

Jalur kedua merupakan jalur nonYudisial yang tidak melibatkan hukum. Jalur ini dapat dilakukan dengan cara negosiasi, mediasi, konsoliasi, dan good office. Baik jalur Yudisial maupun non-Yudisial dapat ditempuh oleh pihak-pihak yang bersengketa. Mereka diberikan keluasan untuk memilih jalur yang mereka inginkan, hal tersebut telah sesuai dengan isi dari Pasal 33 Ayat (1) Bab VI Piagam PBB.

\section{Langkah-Langkah Peyelesaian Sengketa} Pulau Takeshima/Dokdo oleh Jepang dan

\section{Korea Selatan}

Jepang dan Korea Selatan jelas memiliki perbedaan pada dasar klaim mereka terkait kepemilikannya atas Pulau Takeshima/Dokdo. Jepang memberikan dasar klaim yang kuat dengan memperlihatkan berbagai surat resmi yang menyatakan jika pulau tersebut telah menjadi milik Jepang dengan nama Takeshima.

Pulau yang oleh Jepang dianggap tidak memiliki pemilik ini tidak pernah diberikan kepada Korea Selatan seperti pulau-pulau lainnya yang tercantum dalam Pasal 2 dari 
Bab II Perjanjian San Fransisco yang berjudul Territory.

Sementara itu, Korea Selatan memiliki dasar klaim yang berasal dari fakta sejarah dan letak geografis. Meskipun terlihat tidak memiliki dasar klaim sekuat Jepang, fakta sejarah Korea Selatan terkait Pulau Takeshima/Dokdo tetap tidak dapat diabaikan begitu saja. Dengan perbedaan dasar klaim ini, keduanya memiliki perbedaan dalam melakukan upaya penyelesaian sengketa $\mathrm{Pu}$ lau Takeshima/Dokdo.

Jepang terlihat percaya diri dengan dasar klaim yang mereka miliki. Hal ini terlihat dari upaya Jepang yang ingin membawa masalah sengketanya bersama Korea Selatan ke Mahkamah Internasional. Jepang melakukan upaya tersebut sebanyak tiga kali, yakni di tahun 1954, 1962, dan 2017.

Namun, semua upaya Jepang ditolak oleh Korea Selatan dengan alasan jika tidak ada masalah yang berkaitan dengan Pulau Takeshima/Dokdo. ${ }^{67}$ Dengan sikap Korea Selatan yang tidak kooperatif ini, usaha yang telah Jepang rencanakan tidak pernah terwujud atau dapat dikatan masih tertunda.

Berbeda dengan Jepang, Korea Selatan memilih melakukan kegiatan diplomasi sebagai upaya penyelesaian sengekta Pulau Takeshima/Dokdo. Upaya ini disambut baik oleh Jepang, sehingga keduanya telah beberapa kali melakukan pertemuan untuk melakukan negosiasi terkait sengketa tersebut. $^{68}$

Pada tahun 1998, dua tahun pasca Korea Selatan dan Jepang meratifikasi UNCLOS keduanya melakukan negosiasi untuk menyelesaikan sengketa Pulau Takshima/Dokdo. Hal yang dibahas ialah batas ZEE, Korea Selatan menetapkan Pulau Ullengdo sebagai garis dasar klaim ZEE-nya, sementara Jepang menggunakan Liancourt Rocks (Pulau Takeshima/Dokdo) sebagai garis dasar klaim ZEE negaranya. ${ }^{69}$ Keduanya saling tidak terima dengan klaim yang dilontarkan oleh masing-masing negara.

Pada akhirnya agar kedua negara ini dapat menikmati hasil laut dari Laut Jepang tanpa perlu mengusik Pulau Takeshima/Dokdo, dibentuklah Perjanjian Perikanan 1998 (The Fisheries Agreement).

Perjanjian tersebut memberikan kesepakatan jika zona perikanan ekslusif di Laut Jepang adalah 35 mil laut untuk Jepang dan 35 mil laut untuk Korea Selatan. ${ }^{70}$ Artinya, kedua negara dapat menangkan ikan dalam jumlah tertentu dari batasan wilayah yang telah ditentukan.

Perjanjian ini akan mulai berlaku pada 22 Januari 1999, hal-hal lainnya akan diatur oleh

67 Paramitha, Op.cit. hlm. 5.

68 Syafitri, Op.cit. hlm. 10.

69 Paul O'Shea, (2012), Playing the Sovereignty Game: Understanding Japan's Territorial Disputes, Diakses pada (__ ), South Yorkshire: http://etheses.whiterose.ac.uk/2212/3/O\%27Shea\%2C_Paul.pdf.

70 Ibid. 
Komisi Perikanan Gabungan (Joint Fisheries Committee). ${ }^{71}$

Negosiasi selanjutnya dilaksanakan pada April 2006, negosiasi ini bermula saat Jepang mengumunkan akan melaksanakan riset ilmiah untuk meneliti fitur geografi Laut Jepang yang di dalamnya juga mencakup Pulau Takeshima/Dokdo. ${ }^{72}$ Negosiasi berlangsung sukar dan dipenuhi ketegangan tanpa menemukan solusi penyelesaian sengketa. Kesepakatan yang keluar hanya menetapkan jika Jepang akan menunda riset yang telah mereka rencanakan sebelumnya. ${ }^{73}$

Pada tahun yang sama, Roh Moo-hyun sebagai Presiden Korea Selatan saat itu memberikan special statement untuk memperjelas sikap negaranya terhadap hubungan Korea Selatan-Jepang. Korea Selatan memutuskan untuk bersikap lebih keras dengan membebaskan diri dari penyelesaian sengketa melalui mekanisme/prosedur wajib UNCLOS. ${ }^{74}$ Mekanisme/prosedur ini merupakan salah satu cara menyelesaikan sengketa yang tertuang dalam Pasal 287 Bab XV UNCLOS 1982 dengan isi sebagai berikut:

"Negara-negara Peserta Konvensi ini harus menyelesaikan setiap sengketa antara mereka baik perihal interpretasi atau penerapan Konvensi ini dengan cara damai sesuai dengan Pasal 2 Ayat (3) Piagam PBB (Perserikatan Bangsa-Bangsa) dan untuk mencapai tujuan tersebut, harus mencari penyelesaian sengketa dengan cara sebagaimana ditunjukkan dalam Pasal 33 Ayat (1) Piagam tersebut.“. 75

Hasil dari Perjanjian Perikanan 1998 memberikan negosiasi dasar jika Pulau Takeshima/Dokdo dapat dijadikan titik pangkal bagi Jepang dalam menetapkan garis yang menandakan batas wilayah lautnya dengan Korea Selatan, sementara Pulau Ullengdo akan tetap menjadi titik pangkal Korea Selatan. ${ }^{76}$ Namun, sejalan dengan pembebasan diri Korea Selatan dari mekanisme/prosedur wajib UNCLOS, maka Korea Selatan tidak lagi mengakui pulau tersebut sebagai titik pangkal milik Jepang. ${ }^{77}$

Masih di tahun yang sama, Korea Selatan memutuskan untuk membentuk Gas Hydrate $R \& D$ Organization yang berada di bawah The Korea Institute of Geoscience \& Mineral Resources untuk melakukan kegiatan pengeboran di cekungan Ulleung sekitaran pulau Takeshima/Dokdo. ${ }^{78}$

Kegiatan ini menghasilkan penemuan baru, sekitar 600 juta ton gas hidrat diketahui berada di daerah cekungan Ulleung, Laut Jepang. ${ }^{79}$

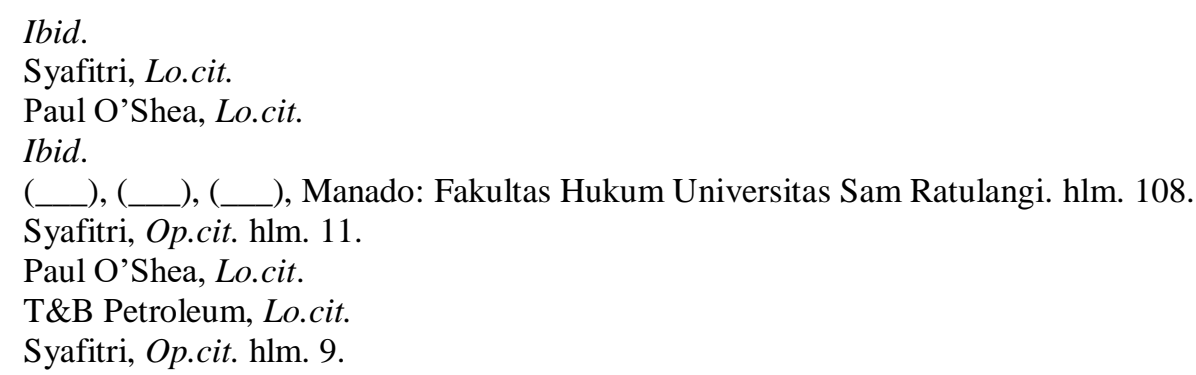


Penemuan sumber energi baru membuat Jepang maupun Korea Selatan semakin tidak dapat melepaskan Pulau Takeshima/Dokdo. Hubungan yang semakin menegang juga disulitkan dengan mundurnya Korea Selatan dari penyelesaian sengketa menggunakan mekanisme/prosedur UNCLOS. Pada akhirnya, semua negosiasi yang telah dilakukan berakhir dengan kesia-sian tanpa menghasilkan solusi dalam penyelesaian sengketa.

Sengketa antara Jepang dan Korea Selatan yang memperebutkan Pulau Takeshima/Dokdo telah berlangsung berpulupuluh tahun lamanya. Masih belum ada solusi yang tepat untuk menyelesaikan sengketa tersebut. Jepang dan Korea Selatan selalu menambah daftar klaim nya dari awal sengketa hingga terkahir di tahun 2018, dimana Jepang meresmikan eksebisi permanen terkait dokumen, artikel, dan foto yang memihak klaim Jepang terhadap Pulau Takeshima/Dokdo. ${ }^{80}$

Korea Selatan yang tidak mau menempuh jalur hukum dalam menyelesaikan sengketa dan memilih jalur diplomatis terbukti hanya memberikan hambatan dalam penyelesaian sengketa yang ada.

\section{KESIMPULAN}

Sengketa Pulau Takeshima/Dokdo merupakan sengketa hukum yang memiliki mekanisme penyelesaian dengan jalur non-
Yuridis, dengan cara bernegosiasi. Negosiasi pertama terjadi di tahun 1998, membahas batas ZEE dan hasilnya ialah Pulau Ullengdo masuk ke dalam teritorial Korea Selatan. Negosiasi ini juga menghasilkan The Fisheries Agreement, yang menetapkan zona perikanan ekslusif di Laut Jepang adalah 35 mil laut untuk Jepang dan 35 mil laut untuk Korea Selatan.

Negosiasi kedua dilaksanakan pada April 2006 dengan penuh ketegangan. Korea Selatan berhasil menekan Jepang untuk menunda riset yang akan mereka lakukan disekitaran pulau Takeshima/Dokdo. Korea Selatan di tahun 2006 membebaskan diri dari penyelesaian sengketa UNCLOS, kemudian didirikannya eksebisi permanen oleh Jepang terkait pulau Takeshima/Dokdo, semakin menambah ketegangan hubungan kedua negara.

Ketidakmauan Korea Selatan untuk membawa sengketa ke dalam Mahkamah Internasional hanya menghambat penyelesaian sengketa dan memberikan ketidakefektifan. Jadi, penelitian ini menyimpulkan jika semua negosiasi yang telah dilaksanakan masih belum memberikan penyelesaian yang jelas terkait status kepemilikan Pulau Takeshima/Dokdo.

\section{DAFTAR PUSTAKA}

\section{Jurnal}

Anniza Kemala, (Juli, 2018), Globalisasi Industri Hiburan Jepang Dan Korea:

80 World, Lo.cit. 
Pengaruh Terhadap Perspektif Publik Antar Negara, Global: Jurnal Politik Internasional, Volume 20, Nomor 2.

Byong-Jae Ryu, (2016), Gas Hydrates in The Deep Water Ulleung Basin, East Sea, Korea, Geophysical Research Abstracts, Volume 18, Nomor (__ $)$.

Dian Adilia Sarsa Gardina, (2018), Sengketa Pulau Takeshima (Dokdo) Antara Jepang Dan Korea Selatan Dalam Perspektif Realisme, UNPAS REPOSITORIES \& SCIENTIFIC JOURNALS, Volume 2, Nomor (__ $)$.

Fauzia Dyah Ayu Paramitha, (2013), Strategi Jepang Dan Korea Selatan Dalam Menyelesaikan Sengketa Teritorial Pulau Takeshima/Dokdo, Jurnal Analisis Hubungan Internasional, Volume 2, Nomor 3.

Firman Budianto, (2015), Tinjauan Buku Anime, Cool Japan, dan Globalisasi Budaya Populer Jepang, Jurnal Kajian Wilayah, Volume 6, Nomor 2.

Ida Primayanthi, (2015), Mekanisme Penyelesaian Sengketa Internasional (Studi Kasus Nikaragua-Amerika Serikat)" (_), Volume 3, Nomor 2.

Julianto Jover Jotam Kalalo, (2016), Penyelesaian Sengketa Terhadap Kasus Imunitas Negara Melalui ICJ (International Court of Justice)/Mahkamah Internasional, Jurisprudentie: Jurusan Ilmu Hukum Fakultas Syariah dan Hukum, Volume 3, Nomor 2.

Utami Gita Syafitri, (2013), Sengketa Pulau Dokdo Antara Jepang Dan Korea Selatan, Jurnal of USU: International Law, Volume 1, Nomor 2.

\section{Skripsi}

), (__ $),\left(\_\right.$), Manado: Fakultas Hukum Universitas Sam Ratulangi.

\section{Internet}

), (1904), Protectorate of Japan over Korea, Diakses pada (__), DokdoTakeshima.com: https://www.dokdotakeshima.com/wordpress/wp- content/images/japan-koreatreaty5.jpg.

), (2009), Korea's Political Situation in 1905 and Japan's Annexation of Dokdo, Diakses pada (__ $)$, DokdoTakeshima.com: https://www.dokdotakeshima.com/koreas-politicalsituation-dokdo.html.

Aldean Tegar Gemilang, (2015), Dampak Sengketa Pulau Dokdo/Takeshima Korea Selatan-Jepang Terhadap Perkembangan Hallyu Di Jepang Tahun 20122015, Dikases pada (__ $)$, Digital Liberary-Perpustakaan Pusat UNIKOM: https://elib.unikom.ac.id/gdl.php?mod= browse\&op=read\&id=jbptunikomppgdl-aldeantega-33503.

Arata Yokokawa, (2015), Takeshima, Diakses pada (_), (_ _ https://www2.jiia.or.jp/en/pdf/digital_library/Yokokawa_takeshima.pdf.

BBC, (2012), South Korea's Lee Myung-Bak Visits Disputed Islands, Diakses pada (_ $)$, BBC: https://www.bbc.com/news/world-asia19204852.

Choe Sang Hun, (2008), Desolate Dots in the Sea Stir Deep Emotions as South Korea Resists a Japanese Claim, Diakses pada (_), The New York Times: https://www.nytimes.com/2008/08/31/ world/asia/31islands.html.

Choe Sang Hun, (2011), Japanese Lawmakers Denied Entry in South Korea, Diakses pada (__ ), The New York Times: https://www.nytimes.com/2011/08/02/ world/asia/02korea.html.

Egie Sagita, (2010), Upaya Diplomatik Korea Selatan-Jepang Terhadap Penyelesaian Sengketa Kepulauan Dokdo, Diakses pada (__), (__ ): https://vdocuments.site/jbptunpaspp-gdl-egiesagita514-1-skripsi-i.html.

Embassy of The Republic of Korea in The Republic of Kenya, (2006), Special Message by President Roh Moo-Hyun on Korea-Japan Relations, Diakses 
pada

$\mathrm{http}: / /$ overseas.mofa.go.kr/ke-

en/brd/m_10548/view.do?seq=613445

$\& \operatorname{srchFr}=\& a m p ; \operatorname{srchTo}=\& a m p ; s r c h W o$

rd=\&amp;srchTp=\&amp;multi_itm_se

q=0\&amp;itm_seq_1=0\&amp;itm_seq

_2=0\&amp;company_cd=\&amp;comp

any_nm $=\&$ page $=8$.

Irvan Sjafari, (2013), Invasi K-Pop Juga Terasa Di Jepang: Sebuah Catatan, Diakses pada (__ ), Kompasiana.com: https://www.kompasiana.com/jurnalge mini/552b3fee6ea834512d552d27/inva si-kpop-juga-terasa-di-jepang-sebuahcatatan.

Jeffrey Hays, (2013), South Korea and Japan Dispute over The Takeshima-Dokdo Island and Japan Sea Name, Diakses pada http://factsanddetails.com/japan/cat22/s ub149/item2922.html.

John Chan, (2006), Ketegangan Antara Jepang Dan Korea Selatan Semakin Meningkat Karena Perselisihan Pulau, Diakses pada (__), World Socialist Web Site: https://www.wsws.org/en/articles/2006 /05/japa-m03.html.

KBS World Radio, (2016), Tahun 1940-an: Kemerdekaan Dan Terbagi Duanya Korea, Diaksespada World.kbs.co.kr: http://world.kbs.co.kr/special/northkore a/contents/archives/outline/outline_194 0.htm?lang=i.

, (2018), Jepang Kembali Mengklaim Kepemilikan Pulau Dokdo, Diakses Pada (__ ), KBS WORLD RADIO: Http://World.Kbs.Co.Kr/Service/News _View.Htm?Lang=I\&Seq_Code $=5145$ 6.

Liputan6, (2012), Omg, Jepang Tolak Konser Kpop!, Diakses pada (__), Liputan6.Com:

ttps://Www.Liputan6.Com/Showbiz/Re ad/453570/Omg-Jepang-Tolak-KonserKpop.
Paul O'Shea, (2012), Playing the Sovereignty Game: Understanding Japan's Territorial Disputes, Diakses pada (_), South Yorkshire: http://etheses.whiterose.ac.uk/2212/3/O \%27Shea\%2C_Paul.pdf.

Syafitri, (_), Sengketa Pulau Dokdo Antara Jepang Dan Korea Selatan, (__), (_ ( $)$, ( _ $)$.

T\&B Petroleum, (2010), S. Korea to Tap Gas Hydrate Reserves in East Sea, Diakses pada (__ ), tbpetroleum.com: https://tbpetroleum.com.br/news/skorea-to-tap-gas-hydrate-reserves-ineast-sea/.

The Commissioned Research Report on, Takeshima-related, and Documents, (2017), Commissioned Research Report on the Takeshima-Related Documents FY2016 Cabinet Secretariat Commissioned Research Project Takeshima-, Diakses pada (_ $)$, https://www.cas.go.jp/jp/ryodo_eg/img/data/archivestakeshima03.pdf.

United Nation, (1945), UN Charter, Diakses pada (_), un.org: https://www.un.org/en/sections/uncharter/un-charter-full-text/.

United Nation-Treaty Series, (1951), Argentina, Autralia, Belgium, Bolivia, Brazil,Etc.Treaty of Peace with Japan (with Two Declarations), Diakses pada (__), San Fransisco: https://treaties.un.org/doc/publication/unts/volume 136/volume-136-i-1832-english.pdf. , (1966), JAPAN and REPUBLIC OF KOREA Treaty on Basic Relations., Diakses pada (_ _ ), (_ _ ): https://treaties.un.org/doc/Publication/UNTS/Volume 583/volume-583-I-8471-English.pdf.

VOA Indonesia, (2019), Untuk Perbaiki Hubungan, Jepang Dan Korsel Sepakat Adakan KTT Bulan Depan, Diakses pada (_), VO: 
88 Yurispruden Volume 5, Nomor 1, Januari 2022, Halaman 70-88.

https://www.voaindonesia.com/a/untuk -perbaiki-hubungan-jepang-dan-korselmengadakan-ktt-bulan-depan/5178206.html.

Yosi Winosa, (2019), Ini Alasan Jepang Berseteru Dengan Korea Selatan, Diakses pada (__ ), Wartaekonomi.co.id,: https://www.wartaekonomi.co.id/read2 36957/ini-alasan-jepang-berseterudengan-korea-selatan.html.

\section{Buku}

Rianto Adi, (2004), Metodologi Penelitian Sosial dan Hukum, (__ $)$; Granit. 